\title{
Tenets of Wesleyan Evangelical Revival in Mainline Protestant Churches in Nigeria
}

\author{
Eugene Ikechukwu Ukaoha ${ }^{1,2}$ \\ ${ }^{1}$ Department of Religion and Cultural Studies, University of Nigeria, Nsukka, Nigeria \\ ${ }^{2}$ West Africa Theological Seminary, Lagos, Nigeria
}

Copyright $\odot 2018$ by authors, all rights reserved. Authors agree that this article remains permanently open access under the terms of the Creative Commons Attribution License 4.0 International License

\begin{abstract}
This paper focuses on the Wesleyan Evangelical Revival, which is the precursor of the mainline Protestant Missions in Nigeria. The main purpose of this work is to examine how the mainline Protestant Churches in Nigeria align themselves with the main tenets of the Wesleyan Revival. The study therefore employed the historical and phenomenological approach. Personal communications or oral interviews and participant observation were the instruments used. The main findings of this study among others show that: The main doctrinal emphases of the Wesleyan Evangelical Revival are new birth/conversion experience and sanctification/holiness of heart and life. The four mainline Protestant churches, namely, Methodist, Anglican, Presbyterian and Baptist align themselves with the tenets of Evangelicalism. The churches understand and emphasize the scriptural doctrine of salvation. The study however noted that there are divergent views about the meaning of the term "Christian Perfection" or "Entire Sanctification" as taught by John Wesley. It therefore noted the need for harmonization of views on this central tenet of the Wesleyan Revival. It then recommended among other things that in order to adequately align itself with the scriptural doctrine of salvation and holiness, the Church in Nigeria should be intentional in prayer, Bible study, teaching, practical living and mentoring on salvation/ holiness. In conclusion, therefore, there is need for harmonization of views and consistent teaching/preaching on these central and crucial tenets of the Wesleyan Revival. The Church in Nigeria needs to go back to God and cry out to Him in repentance to have mercy on us and revive us again.
\end{abstract}

Keywords Tenets, Wesleyan, Evangelical, Revival, Protestant, Missions, Entire Sanctification, Christian Perfection

\section{Introduction}

The Wesleyan Evangelical Revival of the $18^{\text {th }}$ and $19^{\text {th }}$
Century England and America was the precursor of the Protestant mission churches in Nigeria. According to Achunike [1], "Wesley is the spiritual and intellectual father of modern Holiness and Pentecostal Movement that issue from Methodism within the $19^{\text {th }}$ century."Achunike [1] stresses that Wesleyan theology is based on two crisis experience of Conversion or Salvation from actual committed sins, and Sanctification or Cleansing from the Adamic nature, the inbred or inward root of sin, which Wesleyans variously call "Entire Sanctification," "Second Blessing," Perfect Love," according to Burgess[2]. This was the brand of Christianity transported to Nigeria.

It is the thesis of this paper that mainline Protestant churches in Nigeria have deviated from the tenets of Evangelicalism, which is the root of their theology and liturgy and have followed after Prosperity Gospel with its undue emphasis on materialism without a corresponding life of righteousness and holiness. The mainline Protestant churches started well, but along the line, there was the problem of dead orthodoxy, lack of revival fire and lack of evangelism and miracles in the older churches. Steward [3], observes that the evangelistic efforts of these older churches lacked both spiritual and Pentecostal qualities. There were no revivals, and no miracles to confirm the mighty powers of the Almighty God among the Christians. Worse still, was that some of the converts of these earlier church denominations were still holding on to their beliefs and ideas about the traditional worship in their former ways of life and manner.

It was the need to bring revival in the mainline Protestant churches that led to the Pentecostal movement in Nigeria in 1918. The revival started through a prayer band, organized by a group of Christians at St. Savior's Anglican Church, Ijebu Ode, led by Joseph B. Sadare. The group was first named The Precious Stone Society and then later changed to The Diamond Society[4]. This happened during the year of influenza epidemics. Thus, the brethren were moved to provide solution to the ravages of the influenza year.

The revival that hit Nigeria in the early 1970s laid emphasis on repentance, salvation, holiness, healing, faith, 
and evangelism. However, the introduction of the Prosperity Gospel with its overwhelming emphasis on wealth and health, fueled by abject poverty that had plagued and ravaged many Nigerians after the civil war was probably a bane than a blessing. The Prosperity Gospel appears to be a perverted, distorted and deficient Gospel that pushed aside the scriptural teaching of salvation and holiness and replaced it with undue emphasis on material possession. This has led some to believe that if they could exercise enough faith and pray hard they could get whatever they desire even if they were living in sin.

Olaiya[5], quips:

This easy blend of faith, grace, liberty and prosperity, which focused on "the abundant life," produced a Church that craved affluence and luxury, that was clothed in pride and that was shamefully bound in sin. Many preachers had abandoned the message of the joy of salvation and the transformation from $\sin$ to righteousness for the lure of the comforts that money could bring. The result was devastating. It produced a monstrous Church that on the one hand was Christ believing and tongue talking, but on the other hand was sin bound, adorned in pride and arrogance and spiritually destitute, heading down the slippery slope of error. No wonder that some Western critic would say that the African Christianity was a mile wide and only an inch deep.

Apart from the danger posed by the popular Prosperity Gospel, there is also the problem of syncretism. Christianity was successfully planted in Nigeria over 175years ago, yet Christianity in Nigeria is regarded as one mile wide but one inch deep. Why is it that in times of crisis many professing Christians still resort to African Traditional Religion? Why are there so many traditional religious practices such as divination, witchcraft, sorcery, necromancy, use of charms or juju and so forth in the church today? Why is it that Nigerians are said to be the most happiest and religious people on the earth and yet Nigeria is branded as one of the most corrupt countries in the world where forty eight percent of over 180 million Nigerians are Christian? Today many African scholars and theologians are calling for an authentic African Christianity that is rooted and relevant to African culture and people. It is against this background that this work is carried out to motivate the church in Nigeria to align itself completely with the Scriptural teaching and preaching of the message of salvation and holiness that was the cornerstone of Wesleyan revival of the $18^{\text {th }}$ century.

\subsection{Statement of the Problem}

The question that agitates the mind is the extent to which contemporary Nigerian Christianity shares resemblance with the Wesleyan Revival that laid its foundation. This is essential because if Christianity in Nigeria today is to remain relevant there is need for the Church to go back to the scriptural preaching and teaching of salvation and holiness.

Steward [3], observes that during the period of seventy six years (1842-1918) of the history of the church in Nigeria the combined efforts of the Methodist, Anglican, Presbyterian, Baptist, Roman Catholic in evangelizing the different parts of the country yielded the spiritual harvests of making over forty eight percent of Nigerian heathens become Christians. Those Nigerians who became Christians during this period were Christians both inwardly and outwardly. The heathen people around them knew and testified that they were Christians. The general belief then was that 'if you are a Christian, you are a Christian, and if you are a heathen, you are undoubtedly a heathen.'

Yet, there was the problem of dead orthodoxy. There was lack of revival fire, evangelism and miracles in the older churches. According to Steward [3], it was observed that the evangelistic efforts of these older churches lacked both spiritual and Pentecostal qualities. There were no revivals, and no miracles to confirm the mighty powers of the Almighty God among the Christians. Worse of all was that some of the converts of these earlier church denominations were still holding their beliefs and ideas about the traditional worship in their former ways of life and manner.

\subsection{Purpose of Study}

The main purpose of this study is to assess the tenets of the Wesleyan Evangelical revival in the Protestant mission churches, and specifically:

1. To assess the tenets of Wesleyan Evangelical revival in the mainline Protestant churches in Nigeria.

2. To examine the main doctrinal emphases of the Wesleyan revival, which are the roots of Evangelicalism.

3. To show how the mainline Protestant churches in Nigeria align themselves with the scriptural teaching on salvation and sanctification.

4. To suggest ways the Church in Nigeria can align itself with the scriptural preaching/ teaching of salvation and holiness.

\subsection{Significance of Study}

In terms of significance, this study wouldprobably motivate the churches and individual Christians to go back to biblical orthodoxy and revivalism. This study also willbe of relevance to the contemporary Nigerian Christianity that seems to be weakened in biblical content and character. It could also provide some practical help for Christian workers and teachers of the Word on the doctrine of salvation and holiness. Besides, it would add to the body of existing literature on the subject matter as well asbe a resource material on revival and missions in the Nigerian Christianity, especially the Scriptural preaching and 
teaching of salvation and holiness.

\subsection{Limitations of Study}

There is no perfect work of scholarship. Perhaps, there are things that the researcher could have done to improve the quality of this work. First, to note is the researcher's inability to assess several books and other internet resources on Evangelical Christianity and revivalism, especially on Wesleyan Revival that, if available could have enriched the work. Secondly, this research was delimited to Nsukka and Lagos only and thus the findings may not be used as a generalization to the entire country, perhaps a broader scope could have yielded a different or better result.

Finally, the researcher's personal bias, idiosyncrasy or perspectives may have reflected in his interpretation of certain phenomenon, which could have also affected the quality of the work. Nevertheless, this work was aimed at assessing the tenets of the Wesleyan Evangelical revival in the mainline Churches in Nigeria and to observe how the churches align themselves with these tenets, especially the Scriptural doctrine of salvation and holiness and could be judged from that standpoint.

\subsection{Definition of Terms}

Defining a word clarifies its meaning. Therefore the following key and related terms that constituted the title of this work will be defined as follows:

Revival: This means "God's quickening visitation of his people, touching their hearts and deepening his work of grace in their lives. 'Revive' is the AV (KJV) word for this process of spiritual reanimation (Ps. 85:6; Hab. 3:2) 'revivedness' would be the appropriate term to describe its result" Ferguson [6]. The Reformation, the Evangelical Revival in Britain, the first and second Great Awakening in America, the Welsh Revival of 1904-05, and the East African Revival are examples of revival.

Protestant Missions: Refer to the missionary movement following the Reformation in the $16^{\text {th }}$ century led by Martin Luther.

Protestantism: "The word derives from the Protestatio of the pro-reform representatives at the Diet of Speier (1529) against Roman Catholic practices. It covers all those within the Christian tradition outside of Roman Catholicism and orthodoxy" Ferguson [6].

Mainline Protestant Churches: Mainline Protestant churches in this work refer to the evangelical churches planted in Nigeria between the $18^{\text {th }}$ and $20^{\text {th }}$ century by the Protestant missions. According to Ukaoha, [7] these include Methodist, Anglican, Presbyterian, Baptist, Qua Iboe Church, Sudan Interior Mission (SIM)/Sudan United Mission (SUM) (now known as Action Partners), Evangelical Church of West Africa (now Evangelical Church Winning All). The main doctrinal emphases of the mainline Protestant churches are salvation and sanctification or holiness. The mainline churches also stress on social gospel, social justice or human development.

Mission/Missions: The term mission is difficult to define. There are no universally acceptable definitions of the word among evangelical scholars, especially those involved in mission studies.However, mission is derived from the Latin mitto, which is a translation of the Greek apostello, which means "to send" [8]. The Hebrew verb is salahand the Scriptures also employ the cognates apostolos, "apostles," which means "the one sent," and apostole ("apostleship"), which implies "the function of being sent, referring to one being sent and his function" [9].

In contrast to mission, the word missions, according to George Peters (quoted in A. Scott Moreau), is "a comprehensive term including the upward, inward and outward ministries of the church. It is the church as 'sent' (a pilgrim, stranger; witness, prophet, servant, as salt, as light, etc. in this world" [8]. He maintains that missions is the actual work and practical realization of the mission of the church.

Baker's Evangelical Dictionary of Biblical Theology defines mission as "the divine activity of sending intermediaries, whether supernatural or human, to speak or do God's will so that his purposes for judgment or redemption are furthered" [9]. Agha [10] definesChristian missions as "sending Christians out to proclaim the Gospel of Christ to the unconverted throughout the world according to the Great Commission by Christ." For the purpose of this study, Christian missions can be defined as doing God's work across socio-cultural, ethnic and linguisticbarriers/boundaries in order to reach; win, teach and disciple nations for Christ and to make them a part of God's church and kingdom here on earth.Missions involve going, sending, praying and giving.

Missionary: A missionary is one who is sent. An apostle (missionary) is one sent to preach the gospel in regions beyond, where the name of Christ has not been named or mentioned.Stephen Gaukroger in George Verwer defines a cross-cultural missionary as "One who is commissioned and sent out by his or her local church to cross cultural boundaries in order to be a witness for Jesus Christ. These boundaries may be those of language, geography, or society. He or she would also intentionally: introduce people to Christ by his or her life, attitudes, actions and words; seek to introduce those who came to Christ to join with others in fellowship of a church. A church will need to be planted if it doesn't exist"[11].

Tenet: Tenet is defined as, "One of the principles or beliefs that a theory or larger set of beliefs based on: one of the basic/central tenets of Christianity" [12]. Therefore the tenets of Wesleyan Evangelical revival refers to the teaching or system of beliefs on which the Wesleyan Revival was based, which include personal faith in the Lord Jesus Christ and the work of the Holy Spirit in the life 
of the Christian leading to holiness of heart and life or Christlikeness, including an active life of witnessing and winning souls for Christ.

\subsection{Biblical/ Theological Framework: Wesleyanism/ Wesleyan Theology}

This study adopts the biblical and theological framework of holiness according to Wesleyanism/Wesleyan theology. According to the Vine's Expository Dictionary of Old and New Testament Words[13], the noun qodesh means: "holiness" Ex. 15:11; "holy thing" Num. 14:15; and "sanctuary" Ex. 36:4. The verb qadesh or qadash, "to be holy; to sanctify" in the Old Testament means "to be holy" Ex. 29:37; Lev. 6:18 or "to sanctify": "Hear me, ye Levites sanctify now yourselves, and sanctify the house of the LORD God of your fathers, and carry forth the filthiness out of the holy place" (2 Chron. 29:5). The Greek word hagiasmos is translated "holiness" in the KJV of Rom. 6: 19, 22; 1 Thess. 4:7; 1Tim. 2:15; Heb. 12:14 means (a) separation to God (1 Cor. 1:30; 2 Thess. 2:13; 1 Pet. 1:12); (b) the resultant state, the conduct befitting those so separated (1Thess. 4:3, 4, 7). The term "holy" and its cognate words, such as "holiness," "holily," and "holy" occur in the Scriptures at least 120 times in relation to material objects and to men [14].

Reasoner[15] avers that the word "holy" appears 842 times in the O.T. and conveys the meaning separation, glory and purity. The concept of separation means that something is unapproachable because of danger or set aside for moral excellence and worship. This implies that God is holy both in His moral excellence/perfection as well as in His separateness from sin/sinners. The Book of Habakkuk records that God is of purer eyes to look or behold iniquity (1:13). Oswalt[16] argues that the word "holy" is also used with reference to other gods and other religions. However, the difference between the concept of holiness in Christianity and other religions is that in the latter God's holiness is unapproachable but in Christianity God not only manifests His holiness ethically/morally but He shares the same with His children, because God says, "Ye shall be holy: for I the LORD your God am holy" (Lev. 19:2 KJV).

Biblically, holiness or sanctification comes from the Hebrew word qodesh or Greek hagiasmos [13], which means to be set apart for a sacred or godly use; it also means to be pure or holy. Thus, holiness is a state or quality of being pure in heart, mind and body. It is moral integrity or uprightness of character. Oswalt[16] refers holiness to conformity to the character of God and a way of behaving, which is expected of God's people. He maintains that, "The fate of the Christian Church in America and around the world depends on what the Church does with the biblical doctrine of holiness" [16].

\subsection{Clarifying the Concept of Mission, Revival and Evangelicalism}

An attempt is made to clarify the concept/meaning of the following terms as used in this work: Missions, Revival, and Evangelicalism/Evangelism

Mission: The word "mission" comes from the Latin "MITTO," which means "to send." [8] The Greek word "APOSTOLOS" or "APOSTELLO" means "One sent forth," or "to send." [9] [13]. The word is used to describe the Twelve Apostles chosen by the Lord Jesus Christ for special training and ministry. Paul was also called an apostle, even though he was not one of the Twelve and did not accompany them during the earthly ministry of the Lord Jesus, but was called and commissioned by the Lord Himself as an apostle to the Gentiles. The word was also used for other people in the NT, like Barnabas, Andronicus and Junia. Cheesman[17] states that, "a missionary is someone who is sent from his people or church to another people; someone who has crossed a cultural barrier to minister the love of Christ to another people." Thus, a missionary is one who is sent forth to preach the good news across a cultural or language barrier and who should live among the people and learn their language and culture in order to communicate to them effectively.

Revival: There is no clear consensus among African Christians as to the meaning of the word revival. To some, the word is used loosely to describe prolonged and organized evangelistic campaigns, renewal, or extensive church growth. To others, revival means a programme, which consists of series of meetings with inspired messages, exuberant worship, including making altar call for salvation and healing. According to Burgess [2], "The origin of this organized revival meetings dates back to the $19^{\text {th }}$ century American revivalism, associated with the ministry of Charles Finney and his popular Lectures on Revival."

It is important to define revival in terms of the divine and human agency involved as well as its communal dimension. Thus, Burgess [2] defines Christian revival as "a communal event, initiated by the Holy Spirit, which assumes the element of decline, out of which believers are called to renewed heights of spiritual vitality and moral probity, issuing in efforts to spread the gospel in and beyond the local community and resulting in a widespread sense of sorrow for sin, extensive conversion experiences and altered religious and socio-cultural landscapes." There is usually a divine-human synergism in the redemptive work of God; God and man cooperating together for the fulfillment of God's will and work. Thus, when God's people humble themselves and seek the face of God and call upon His holy name in truth and spirit, then God will answer from heaven and pour out His Spirit upon His people. Thus, revival is a divine and human initiated phenomenon, which can have a communal or national dimension, resulting in genuine repentance and salvation as well as socio-cultural transformation.

Theologically, revival may be defined as an overwhelming experience of the Holy Spirit's presence in the Church and her surrounding community. Lloyd-Jones quoted in Burgess [2] defines revival as an "experience in 
the life of the Church when the Holy Spirit does an unusual work. In the NT, the Holy Spirit mediates the active presence of God in the Church and the world, thus making it a tangible reality. Orr quoted in Burgess [2] defines revival as "movement of the Holy Spirit bringing about a revival of NT Christianity in the Church of Christ and its related community." Acts 1 and 2 provide the biblical model for revival. Following this model,Stibbe quoted in Burgess [2] enumerates the following features of Biblical revival: "Anointed preaching, radical conviction of sin, passionate intercession, evangelistic worship, miraculous works, kingdom community, social transformation, constant conversions." The presence of the Holy Spirit among the early disciples were manifested by the Holy Spirit empowering them for service (Acts 1:8) speaking to them through prophecy and powerful preaching (Acts 2:14, 17-18) and purifying and filling their heart with love for God and one another (Acts 15:9; 2:39-47). Ukachi [18] says, "Revival is men and women on fire for God."

Evangelism and missions are the by-products of revival.Thus, revival may be defined as an unusual manifestation of the divine presence among God's people through Spirit-led and anointed intercession and preaching, worship and fellowship, evangelism and missions, resulting in extensive conversions, church growth as well as socio-cultural transformation.

Evangelicalism/Evangelism: Evangelicalism means living according to the Gospel. Bebbington[19]states that evangelical with a lower-case initial is occasionally used to mean of the gospel, the term Evangelical, with a capital letter, is applied to any aspect of the movement beginning in the 1730s. He notes four characteristics of Evangelicalism: 1. Conversionism- a stress on the new birth or being born again as taught in passages such as John $3: 3,5$. Biblicism, defined as having a high regard for biblical authority and identification with biblical story. 3 . Crucicentricism- draws attention to teachings that proclaim the saving death and resurrection of the Son of God, Jesus Christ, offering forgiveness of sins and new life. In short, a focus on Christ's redeeming work as central to Christianity. 4. Activism-describes the tendency towards active expression and sharing of the gospel in diverse ways that indicate preaching and social action.

Baur[20] opines that Evangelism refers to preaching the Gospel. This implies that Evangelism is presenting Christ to the lost or dying world (sinners) according to John 3:16, which reads, "For God so loved the world that He gave His only begotten Son, that whosoever believeth in Him should not perish, but have everlasting life" (KJV). Evangelism is a lifestyle of living for and making Christ known.

\subsection{The Eighteenth Century Evangelical Revival}

The Evangelical Revivals refer to the three great revivals that took place in England and North America between $1730 \mathrm{~s}$ and $1860 \mathrm{~s}$, triggered by the preaching of John
Wesley and other leading men like George Whitefield, Charles Wesley, Jonathan Edwards, Charles G. Finney and D.L. Moody.The Evangelicals, reformers and revivalists as the men were variously called were the movers and shakers of the $18^{\text {th }}$ Century North American and England Church and society. Specifically, the Great Awakening of the years 1739-1791 is frequently called the Wesleyan revival and John Wesley was clearly the chosen leader of this spiritual awakening. John Wesley was an ordained Anglican priest and his father Samuel Annesley Wesley was also an Anglican priest. John Wesley lived and died an Anglican. But after Wesley's conversion in 1738 he devoted his life to revive the Church of England.

According to Thomson [21],

Wesley's work was parallel to the Great Awakening going on in the American colonies. Wesley was inspired by reading Jonathan Edward's pamphlet on his revival in Northampton. Wesley was also influenced by his friend, George Whitefield who was an itinerant revivalist preacher. Wesley too was an itinerant preacher, evangelist and revivalist. He travelled all over the British Isles, preaching revival and urging Christians to embrace the Gospel.

\subsection{A Brief Historical Account of Christianity in Nigeria}

Christianity was successfully introduced into Nigeria through the opposite ends of the Nigeria's coasts Badagry and Old Calabar in the $19^{\text {th }}$ century, according toAjayi[22]; Ayandele[23]; Maxey [24]. The first Protestant mission society to introduce Christianity in Nigeria was the Methodist Church. Ajayi [22] states that The Rev. Thomas Birch Freeman arrived at Badagry on 24 September 1842, accompanied by William de Graft, his Fante 'assistant missionary', a native of Cape Coast. T.B. Freeman was the Superintendent of the Methodist Mission at Cape Coast. Both missionaries were sent to open an out-station of Cape Coast in Badagry.

Ajayi [22] further remarks that following the Methodist missionary was the Church Missionary Society (CMS) missionary, Rev. Henry Townsend, a young man of 26 , who arrived at Badagry in December 1842 and Abeokuta 4 January 1843. The Presbyterian Church entered into Old Calabar through Rev. and Mrs. Hope Waddell on $10^{\text {th }}$ April 1846. The pioneer Southern Baptist missionary Thomas Jefferson Bowen entered into Yorubaland, Badagry, on $5^{\text {th }}$ August, 1850; Ijaye (February 1852); Ogbomoso (1855). He had wanted to go "Bohoo" (that is, Igboho, a former capital of the Old Oyo Empire to establish the first station there [25].

On $27^{\text {th }}$ July 1857 , during the third Niger Mission, the CMS entered into Igboland under John Christopher Taylor, an Igbo ex-slave. This marks the effective establishment of the Anglican Church in Igboland, including the advent of 
Roman Catholic Church under Father Francis Borghero in Lagos in 1862 and Onitsha (1865) under Father Joseph Lutz, the leader of the Holy Fathers. Also the Sudan Interior Mission (SIM) made their entry into Nigeria in 1893 through three young missionaries, namely, Walter Goman, Thomas Kent and Bowland Bingham [26]

In summary, the Wesleyan revival in England in the $18^{\text {th }}$ century had a far-reaching influence than the revival under Jonathan Edwards within the American colonies, judging from its impact on the socio-religious milieu of this period. Thus, one needs to understand something about the socio-religious background that provided the impetus for revival, a morally bankrupt church and poverty-stricken society. There was need for reforms in the prison, factory workers and child right acts and so forth. Unfortunately, for more than a century and half after the Protestant Reformation, the problem of dead orthodoxy still plagued the spiritual life of the Church.

The Mission churches in Nigeria during the early $20^{\text {th }}$ century had the same problem of dead orthodoxy and lack of revival fires. Thus, early works on the Wesleyan Evangelical Revival laid emphasis on the history of the revival, its doctrinal practicessuch as salvation and sanctification, but none was able to examine how the mainline Protestant churches in Nigeria conform or align themselves with the tenets of this revival which formed the background of their doctrinal emphasis and liturgy. It is to this end that this work was carried out to fill this gap and to make contributions to learning. Besides, this work was undertaken to motivate the churches to align themselves with the Evangelical Christianity that is rich in biblical content and character instead of the cheap and popular Prosperity Gospel that seems to have neglected wholesome preaching and teaching of new birth experience and holy living.

\section{Methodology}

The researcher interviewed 12 clergymen and 8 members of four mainline churches, namely, Methodist, Anglican, Baptist, and Presbyterian. Three clergymen from each church and 8 parishioners, making a total of 20 persons were randomly selected for interview. 10Structured interview questions were designed to find out indices of Wesleyan Evangelical revival (See Appendix 1). The data collected were qualitatively analyzed and used to evaluate the understanding of each church on the Scriptural doctrine of salvation and sanctification (holiness) from the Wesleyan perspective and necessary conclusions were drawn. This study was carried out in Nsukka and Lagos between the month of December 2013 and June/ July, 2014.

\section{Findings}

Ten-structured questions were asked to assess the indices of Wesleyan revival tenets among the four selected churches, namely, Methodist, Anglican, Presbyterian and Baptist. (See Interview Questions attached in Appendix 2). Table 1 shows the result of the analysis.

\subsection{Discussion of Findings}

The mainline Protestant churches show similar understanding of the scriptural doctrine of salvation, however, not all churches show the same understanding of the doctrine of sanctification/holiness, entire sanctification/Christian perfection. In other words, not all the churches agree with all the tenets of the Wesleyan revival. The Presbyterian Church, for instance, claims that they share in this heritage earlier before Wesley. The Baptist Church believes in scriptural holiness but tends towards Calvinism more than Wesleyanism. In general, the Presbyterians, Anglicans and Baptists would subscribe to positional sanctification, also known as initial sanctification, which begins at new birth, but they would not generally hold on to victory over sin. But the Bible teaches that after salvation, believers should press on to perfection which John Wesley calls Christian perfection or entire sanctification. The Methodists, on the other hand, asserts that they align with the holiness teaching of John Wesley himself but not the holiness emphasis of the later holiness movement. However, the historical Methodist message of Scriptural holiness is an emphasis on Christlikeness, which cannot come through discipline and rules, but through faith in the atoning work of Christ. Wesleyans teach that entire sanctification/Christian perfection is synonymous and it happens instantaneously and is progressive.

The doctrinal emphases of the mainline Protestant churches agree with the tenets of modern Evangelicalism. The Evangelicals believe in the Bible as the sole authority and rule of faith and conduct. They believe in the centrality and the vicarious death of Christ on the Cross of Calvary for the redemption of mankind. They preach repentance and faith in the Lord Jesus Christ and salvation by grace through faith. However, Wesleyanism lays more emphasis on the doctrine of holiness of heart and life. 
Table 1. Showing Church Denominations and their Doctrinal Emphases/Understanding of the Tenets of the Wesleyan Revival

\begin{tabular}{|c|c|c|c|c|c|c|}
\hline $\begin{array}{c}\text { Church } \\
\text { Denomination }\end{array}$ & $\begin{array}{l}\text { Main Doctrinal } \\
\text { Emphasis }\end{array}$ & $\begin{array}{l}\text { Understanding of } \\
\text { New Birth } \\
\text { Experience }\end{array}$ & $\begin{array}{l}\text { Understanding } \\
\text { of Holiness/ } \\
\text { Sanctification }\end{array}$ & $\begin{array}{l}\text { Attainability } \\
\text { of Holiness/ } \\
\text { Sanctification }\end{array}$ & $\begin{array}{c}\text { To what } \\
\text { extent can a } \\
\text { Christian be } \\
\text { holy or } \\
\text { perfect? }\end{array}$ & $\begin{array}{c}\text { Understanding of Entire } \\
\text { Sanctification/Christian } \\
\text { Perfection }\end{array}$ \\
\hline Methodist & $\begin{array}{c}\text { Priesthood of } \\
\text { all believers, } \\
\text { Salvation, } \\
\text { justification by } \\
\text { faith } \\
\text { Sanctification, } \\
\text { Water baptism, } \\
\text { Holy } \\
\text { Communion, } \\
\text { Confirmation, } \\
\text { Evangelism, } \\
\text { Christian } \\
\text { perfection, } \\
\text { Ministry of the } \\
\text { Holy Spirit, } \\
\text { Scriptural } \\
\text { holiness }\end{array}$ & $\begin{array}{l}\text { "Ye must be Born } \\
\text { Again" (Jn. 3:3), } \\
\text { New life in } \\
\text { Christ(2 Cor. } \\
\text { 5:17) } \\
\text { All have sinned } \\
\text { and come of the } \\
\text { glory of God } \\
\text { (Rom. 3:16). } \\
\text { Regeneration }\end{array}$ & $\begin{array}{c}\text { Sanctification/h } \\
\text { oliness means } \\
\text { the same; to be } \\
\text { set apart for } \\
\text { holy use } \\
\text { (ceremonial) To } \\
\text { be purified from } \\
\text { sin (ethical } \\
\text { meaning). } \\
\text { Progressive } \\
\text { sanctification, } \\
\text { not } \\
\text { "automatic"; } \\
\text { continuous } \\
\text { cleansing from } \\
\text { sin. }\end{array}$ & $\begin{array}{l}\text { Attainable, } \\
\text { because } \\
\text { "without } \\
\text { holiness no } \\
\text { man shall see } \\
\text { the Lord" } \\
\text { (Heb. 12:14). }\end{array}$ & $\begin{array}{l}\text { Requires } \\
\text { self-denial; } \\
\text { Obedience }\end{array}$ & $\begin{array}{c}\text { Entire } \\
\text { Sanctification/Christian } \\
\text { Perfection is } \\
\text { synonymous and can be } \\
\text { used interchangeably. } \\
\text { Entire Sanctification } \\
\text { means to be holy in } \\
\text { body, soul and spirit } \\
\text { (wholly, entirely, } \\
\text { completely) }\end{array}$ \\
\hline Anglican & $\begin{array}{c}\text { Holiness, } \\
\text { Sanctification, } \\
\text { Repentance, } \\
\text { Baptism } \\
\text { (including } \\
\text { infant baptism) }\end{array}$ & $\begin{array}{l}\text { Turning from sin } \\
\text { to righteousness } \\
\text { and holiness. The } \\
\text { Holy Spirit } \\
\text { regenerating a } \\
\text { sinner into the life } \\
\text { of Christ. }\end{array}$ & $\begin{array}{l}\text { Purity of life/ } \\
\text { cleanliness; } \\
\text { Christlikeness; } \\
\text { Being set apart } \\
\text { unto God; a } \\
\text { state of being } \\
\text { blameless } \\
\text { before God }\end{array}$ & $\begin{array}{c}\text { Attainable } \\
\text { here on earth }\end{array}$ & Strive & $\begin{array}{c}\text { Live a life devoid of sin; } \\
\text { Sanctified by the Word } \\
\text { (Jn. 17:17 }\end{array}$ \\
\hline Presbyterian & $\begin{array}{l}\text { Sovereignty of } \\
\text { grace, The } \\
\text { Bible as the } \\
\text { Rule of } \\
\text { life/faith, } \\
\text { TULIP-Total } \\
\text { Depravity of } \\
\text { Man, Universal } \\
\text { Grace, Limited } \\
\text { Atonement, } \\
\text { Irresistible } \\
\text { Grace, } \\
\text { Perseverance of } \\
\text { the Saints }\end{array}$ & $\begin{array}{c}\text { Conversion } \\
\text { through the help } \\
\text { of the Holy Spirit } \\
\text { /Scripture }\end{array}$ & $\begin{array}{l}\text { Imputed } \\
\text { righteousness; } \\
\text { Progressive } \\
\text { holiness; } \\
\text { Christian } \\
\text { perfection } \\
\text { synonymous to } \\
\text { holiness; God } \\
\text { says, "Be holy } \\
\text { (perfect) "for I } \\
\text { am holy" (Mt. } \\
\text { 5:48; } 1 \text { Pet. } \\
\text { 1:16. }\end{array}$ & $\begin{array}{l}\text { Not attainable } \\
\text { here on earth; } \\
\text { no one can be } \\
\text { perfect; } \\
\text { Attainable but } \\
\text { not "total" or } \\
\text { "complete" } \\
\text { perfection }\end{array}$ & $\begin{array}{l}\text { No yardstick } \\
\text { or measure; } \\
\text { the degree of } \\
\text { one's } \\
\text { commitment } \\
\text { /trust on } \\
\text { God's grace }\end{array}$ & $\begin{array}{c}\text { Progressive } \\
\text { sanctification }\end{array}$ \\
\hline Baptist & $\begin{array}{l}\text { Individual soul } \\
\text { competency, } \\
\text { Priesthood of } \\
\text { all believers; } \\
\text { believers } \\
\text { Baptism; } \\
\text { Regeneration; } \\
\text { Authority of the } \\
\text { Scripture; Sole } \\
\text { authority of } \\
\text { Scripture in } \\
\text { matters of faith } \\
\text { andpractice, } \\
\text { Scriptural } \\
\text { holiness, eternal } \\
\text { security of the } \\
\text { saints. }\end{array}$ & $\begin{array}{l}\text { Salvation by faith } \\
\text { in Christ; } \\
\text { Repentance and } \\
\text { confession; } \\
\text { Acceptance of } \\
\text { Jesus Christ as } \\
\text { personal Lord and } \\
\text { Saviour }\end{array}$ & $\begin{array}{l}\text { Freedom from } \\
\text { original sin; } \\
\text { Heart filled with } \\
\text { love for God } \\
\text { and humans } \\
\text { through the } \\
\text { works of the } \\
\text { Holy Spirit }\end{array}$ & Attainable & $\begin{array}{l}\text { Daily } \\
\text { growth in } \\
\text { God, doing } \\
\text { His will, } \\
\text { obedience }\end{array}$ & Maturity in Christ \\
\hline
\end{tabular}


Each church understands that the new birth or conversion experience or being "born again" are synonymous and means turning from sin to righteousness, repentance and faith towards our Lord Jesus Christ and to accept Him as one's personal Lord and Saviour. Some of the churches show special emphasis on their teaching on salvation. For example, the Baptist doctrine of "soul competency," refers to the freedom of the individual to approach and relate with God based on Christ's atonement. The individual does not need any mediator in order to have access to God other than Jesus Christ, "For there is one God and one mediator between God and mankind, the man Christ Jesus, who gave himself as a ransom for all people" (1Tim.2:5, 6). Both the Baptist and Methodist show special emphasis on the Priesthood of all believers.

The Presbyterian Church show special emphasis on sovereignty of God/grace. The main doctrinal emphasis of the Presbyterian Church is contained in the Apostles' Creed. "God's sovereignty," as taught by John Calvin in the Christian Institute of Christian Religion, is the basis of Presbyterianism, which is reflected in His eternal decrees and His providence. According to John Murray [27]:

God is the arbiter and governor of all things, 'Who, of his own wisdom, from the remotest eternity, decreed what he would do, and now by his own power executes what he has decreed. Whence we assert that not only the heaven and the earth and inanimate creatures, but also the deliberations and volitions of men are governed by his providence and they are directed exactly to their destined end...The will of God is supreme and first cause of all things, because nothing happens but by his command or permission.' The providence of God embraces all events, past, present, future and applies to the evil and as much as the good, to sinful acts as much as the holy acts of men and angels.

However, not all churches show similar doctrinal emphasis or understanding of sanctification/holiness. Methodists understand sanctification or holiness to mean to be progressive not "automatic," but continuous cleansing. Anglicans understand it to be purity of heart/life, Christlikeness. Baptists understand it as freedom from the original sin and a heart filled with love for God and man. According to Wesleyanism, holiness / sanctification can be understood in two senses.

First, in the ceremonial sense of the word, it means to be set apart for a godly or sacred use or simply consecration. This is the sense it is used for objects, persons and places especially in the Old Testament, and somewhat in the New Testament. Secondly, ethically or morally, holiness or sanctification means to be pure or holy, in other words, cleansing or purification from sin. This is the sense it is used mostly in the New Testament and somewhat in the Old Testament. Oswalt says that the difference between the Old Covenant and the New Covenant is that the Old
Covenant is external, whereas the New is internal [16]. So also is holiness in both Covenants. Daniel Steele (in Reasoner), declares that "entire sanctification except in a ceremonial sense was not enjoyed by the Old Testament saints" [15]. Reasoner further clarifies that the ethical concept of holiness was prominent only in the prophetic section of the Old Testament such as Jeremiah 31:31-34; Ezekiel 36:25-29; Joel 2:28-29.

Thus, sanctification/ holiness can be used interchangeably and mean the same. Both come from the same Hebrew root qodesh or Greek hagiasmos, which is translated holiness, to be holy or to sanctify. However, there is a slight difference in meaning and practical application. Whereas, sanctification is the act or process of being made holy or pure; holiness is the resulting state or condition. Sanctification or entire sanctification is the practical application of holiness. The Lord Jesus Christ prayed for His disciples to be sanctified, "Sanctify them through the truth: the word is truth" (John 17:17). The Apostle Paul also prayed for the Thessalonians, "And the very God of peace sanctify you wholly; and I pray God your whole spirit and soul and body be preserved blameless unto the coming of the Lord Jesus Christ" (1Thess.5:23). The Amplified Bible reads thus, "And may the God of peace Himself sanctify you through and through [separate you from profane things, make you pure and wholly consecrated to God]; and may your spirit and soul and body be preserved sound and complete [and found] blameless at the coming of our Lord Jesus Christ [the Messiah]. One could take note of the exact biblical words/phrases used: "sanctify" "wholly, "whole," "make you pure," "through and through," and so on. One could also note verse 24, which says, "Faithful is he calleth you, who also will do it" KJV. "Faithful is He Who is calling you [to Himself] and utterly trustworthy, and He will also do it [fulfill His call by hallowing and keeping you] AMP.

If sanctification/ entire sanctification is not attainable in this life, the Lord Jesus Christ would not have prayed for His disciples to be sanctified, and the Apostle Paul for the Thessalonians to be sanctified wholly, entirely, through and through, their body, soul and spirit and even added that God who has called us is faithful and will do it. Sanctification is not an optional extra but an added preservative and privilege of the true children of God who yearn and desire to be made holy or pure.

All the churches understand sanctification and holiness to mean the same. However, there were divergent views as to the meaning of the term entire sanctification/Christian perfection. Anglicans say it is to live a life devoid of sin; sanctified by the Word. Baptists say it is maturity in Christ. Methodists say that entire sanctification is synonymous with Christian perfection and it means to be holy in body, soul and spirit (wholly, entirely, and completely). Presbyterians say it means progressive sanctification and not attainable here on earth. Whereas, Anglicans, Baptists, and Methodists say that it is attainable in this life. 
Christian perfection is perhaps the least understood of all the Bible doctrines. According to John Wesley:

There is scarcely any expression in the holy writ, which has given more offence than this. The word perfect is what many cannot bear. The very sound of it is an abomination to them; and whosoever preaches perfection (as the phrase is ), that is, asserts that it is attainable in this life, runs great hazard of being accounted by them worse than a heathen man or a publican [28].

In Philippians 3:12, the Apostle Paul disclaimed the perfection which has to do with perfection of knowledge but he claimed the perfection which involves being and doing all for which Christ apprehended him. Thus, Wesley states that instead of refusing or declining to teach it because some people are offended, rather we should go ahead and teach it because it is the word of God. He then described two senses in which Christians are not and in which they are perfect. First, Christians are not perfect in the sense of being free from ignorance, mistakes, infirmities and temptations. Secondly, Christians are perfect, not to commit sin, freed from outward and inward sins/evil tempers, including being sanctified/cleansed from all sins; purified, renewed and their heart filled with pure/perfect love for God and man.

\subsection{Summary of Findings}

1. The Protestant Mission Churches in Nigeria show similar alignment with the tenets of the Wesley Evangelical Revival.

2. It is not all churches show similar understanding of the doctrine of sanctification, holiness or Christian perfection. In other words, not all the churches agree with all the tenets of the Wesleyan revival.

3. The main doctrinal emphases of the Wesleyan Evangelical revival are new birth/ conversion experience and sanctification/holiness of heart and life.

4. The mainline Protestant churches, namely, Methodist, Anglican, Presbyterian and Baptist align themselves with the tenets of Evangelicalism.

5. The churches understand the scriptural doctrine of salvation but their teaching or emphasis on holiness or sanctification is not the same.

6. The term "Christian perfection" appears to be the least understood and confusing doctrine of the Bible.

7. There are divergent views about the meaning of the term Christian perfection such as a state of blamelessness, Christlikeness, maturity, imputed righteousness, progressive sanctification and so forth.

8. John Wesley taught that Christian perfection means loving God with all our heart, mind, soul and strength, such that no wrong temper, none contrary to love remains in the soul; and that the thoughts and words are governed by pure or perfect love. It is perfect/pure love for God and man.

9. Wesley's teaching on Christian perfection can be summarized as follows: First, what it does not mean: freedom from ignorance, infirmities, mistakes, temptations. Secondly, what it means, a Christian is perfect not to commit sin, a Christian is freed from evil thoughts/evil tempers, and purified/cleansed from all sins.

10. The Prosperity Gospel appears to be a perversion of the scriptural teaching of prosperity with its undue emphasis on materialism without a corresponding life of righteousness and holiness without which no man shall see the Lord.

\section{Conclusions}

The main doctrinal emphases of the Wesleyan Evangelical revival are salvation, sanctification/ holiness, entire sanctification/Christian perfection. All the mainline Protestant churches studied align themselves with the scriptural doctrine of salvation. They understand that salvation, new birth/conversion experience, regeneration or being "born again" means the same and is the basis of a person's relationship with God. However, after salvation, believers are called to the highway of holiness. In general, Presbyterians, Anglicans, and Baptists subscribe to positional sanctification, which begins at new birth, on the basis of our shared inheritance or position in Christ. Wesleyans, on the other hand, believe that Christian perfection or entire sanctification is a crisis experience that is both instantaneous and progressive and all believers are called to aspire/strive for a life of holiness, purity of heart or Christlikeness.

Entire sanctification means to be made pure or holy, through and through, entirely, wholly, or completely. It is to be made holy/pure body, soul and spirit. Entire sanctification and Christian perfection means the same. John Wesley says that Christian perfection is "The loving God with all our heart, mind, soul and strength. This implies that no wrong temper, none contrary to love, remain in the soul and that all those words, and actions are governed by pure love." The term Christian perfection is one of the most controversial and offensive doctrines of the Bible, but according to John Wesley, instead of refusing or neglecting to teach it because it is controversial or offensive to some people, rather the Church should continue to teach it consistently because it is the word of God. There are two senses in which Christians are not and in which they are perfect. First, Christians are not perfect in knowledge, they are not perfect in not making mistakes and they are not perfect or free from infirmities or temptations. Secondly, Christians are perfect not to commit sin; they are perfect/ purified from outward and inward sins/evil tempers. Thirdly, the biblical concept of perfection is 
understood in the sense that a person or thing is perfect when it is just what it is designed or intended to be.

The Church in Nigeria should align itself fully with the scriptural teaching of salvation and holiness, entire sanctification/Christian perfection, through intentional prayer, intentional Bible Study, intentional mentoring and intentional teaching. Therefore, there is need for harmonization of views and consistent teaching/preaching on these central and crucial tenets of the Wesleyan revival. The Church in Nigeria needs to return to biblical authority instead of depending on experience, reason or tradition. They need to emphasize repentance and a radical conversation from sin. They need to return to a Christ-centered message instead of a distorted emphasis on signs/wonders, miracles, prophecies and prosperity. And they need to preach a holy life, which begins at the new birth. The church also needs to preach "Christian perfection," but "Christians" cannot go on unto perfection if they have not truly been born again. The Prosperity preachers need to repent and preach sound theologically/biblically balanced message of prosperity. The untrained preachers/pastors need to go to a credible Bible College or Seminary to acquire quality theological training.

\section{Recommendations}

Having examined how the mainline Protestant churches align with the tenets of the Wesleyan Evangelical Revival and based on the findings of this study, the researcher hereby makes the following recommendations:

1. The scriptural doctrine of salvation or new birth experience and holiness of heart/life, which are the main tenets of the Wesleyan Evangelical revival, should be properly, continuously and vigorously taught so that every Christian may be prepared for a life of purpose, faithfulness and fruitfulness in Christ.

2. The Protestant churches in Nigeria should endeavor to maintain the four cardinal tenets of Evangelical
Christianity, namely, conversion, biblical authority, evangelism/missions and the centrality and the vicarious death of Christ on the Cross of Calvary as the basis of redemption for mankind.

3. The Protestant mission churches in Nigeria should be intentional and proactive in their preaching and teaching of salvation and holiness as well as their evangelistic and missionary activities.

4. The Protestant ministers in Nigeria should deepen their knowledge and understanding of the scriptural doctrine of holiness or Christian perfection so as to be able to teach it with greater conviction and applicability.

5. Contemporary Nigerian pastors should emulate John Wesley's life and ministry, especially his teaching on holiness or Christian perfection. It may be useful, for instance, for every minister to own and study John Wesley's 52 Sermons and The Plain Account of Christian Perfection.

6. John Wesley's teaching on Christian perfection should form part of the fundamental doctrines taught to catechumens before/after baptism or confirmation.

7. The church leaders should put in place regular and appropriate discipleship programs for new converts as well as older members. Much emphasis should be placed on corporate and individual holiness and the need for every Christian to model a lifestyle of holiness.

\section{Oral Interviews}

Rev. Dr. Ituma, Ezichi Anya, Personal communications, July 17, 2014

Rev. Dr. Omaka K. Ngele, Personal communications, July 1, 2014

Rev. Ugochukwu S. Chinedu, Personal communications, July 4, 2014 


\section{Appendix I: Personal Profile of the Interviewees}

\begin{tabular}{|c|c|c|c|c|c|c|c|}
\hline $\mathrm{S} / \mathrm{N}$ & Name & Sex & Age & Church & Location & Occupation & $\begin{array}{c}\text { Date of } \\
\text { Interview }\end{array}$ \\
\hline 1 & Omaka K. Ngele & Male & Adult & Presbyterian & Nsukka & Lecturer/Clergy & $1 / 7 / 14$ \\
\hline 2 & Joseph N. Chukwuma & Male & 38 & Anglican & Nsukka & Clergy/Lecturer & $4 / 7 / 14$ \\
\hline 3 & Umanah, Victor Sunday & Male & 39 & Methodist & Nsukka & Evangelist & $28 / 6 / 14$ \\
\hline 4 & Chinedu S. Ugochukwu & Male & 36 & Methodist & Nsukka & Clergy & $4 / 7 / 14$ \\
\hline 5 & Ayandokun, Esther & Female & Adult & Baptist & Lagos & Clergy/Lecturer & $30 / 6 / 14$ \\
\hline 6 & Joseph Akpovbovbo & Male & 52 & Baptist & Lagos & Clergy/Lecturer & $1 / 7 / 14$ \\
\hline 7 & $\begin{array}{c}\text { Donald } \\
\text { OkechukwuNnebedum }\end{array}$ & Male & 31 & Anglican & Nsukka & Clergy/Civil Servant & $30 / 6 / 14$ \\
\hline 8 & Nneoyi U. Arikpo & Male & 40 & Presbyterian & Nsukka & Chaplain & $8 / 7 / 14$ \\
\hline 9 & David C. Ononogbu & Male & 40 & Presbyterian & Nsukka & Parish Priest & $8 / 7 / 14$ \\
\hline 10 & Uchendu, Nene C. & Female & 29 & $\begin{array}{c}\text { Christ Church } \\
\text { Chapel }\end{array}$ & Nsukka & Teacher/PG Student & $13 / 7 / 14$ \\
\hline 11 & ZubairuBitrusSamaila & Male & 38 & $\begin{array}{c}\text { Christ Church } \\
\text { Chapel }\end{array}$ & Nsukka & PG Student & $6 / 7 / 14$ \\
\hline 12 & OgbonnayaElom & Male & 45 & $\begin{array}{c}\text { Christ Church } \\
\text { Chapel }\end{array}$ & Nsukka & Lecturer/PG Student & $6 / 7 / 14$ \\
\hline 13 & Beatrice Nzekwe & Female & 50 & $\begin{array}{c}\text { Christ Church } \\
\text { Chapel }\end{array}$ & Nsukka & $\begin{array}{c}\text { Civil Servant/Asso. } \\
\text { Chaplain }\end{array}$ & $30 / 6 / 14$ \\
\hline 14 & Aliche C.O. & Male & Adult & Methodist & Nsukka & Clergy/Pastor & $13 / 7 / 14$ \\
\hline 15 & Collins Ugwu & Male & 40 & Anglican & Nsukka & Clergy/Lecturer & $14 / 7 / 14$ \\
\hline 16 & BiodunOloyede & Male & 49 & Baptist & Lagos & Accountant/Deacon & $8 / 7 / 14$ \\
\hline 17 & BabatundeAlao & Male & 34 & Baptist & Lagos & $\begin{array}{c}\text { Insurance/Youth } \\
\text { President }\end{array}$ & $9 / 7 / 14$ \\
\hline 18 & EzichiItuma Anya & Male & 52 & Presbyterian & Nsukka & Clergy/Lecturer & $17 / 7 / 14$ \\
\hline 19 & AkanimoAsuquo & Male & 27 & Christ Chapel & Nsukka & $\begin{array}{l}\text { PG Student/Youth } \\
\text { Fellowship President }\end{array}$ & $28 / 7 / 14$ \\
\hline 20 & ChiemekamEzechukwu & Male & 29 & Christ Chapel & Nsukka & PG Student & $6 / 7 / 14$ \\
\hline
\end{tabular}

\section{Appendix 2: Interview Questions}

\section{Department of Religion and Cultural Studies}

\section{University of Nigeria, Nsukka}

Dear Sir/Madam,

\section{INTERVIEW QUESTIONS ON THE TENETS OF WESLEYAN EVANGELICAL REVIVAL IN THE MAINLINE PROTESTANT CHURCHES IN NIGERIA}

Greetings! I am conducting a research on The Tenets of Wesleyan Evangelical Revival in the Mainline Protestant Churches in Nigeria. I wish to find out the tenets of Wesleyan Evangelical Revival in four mainline Protestant Churches in Nsukka/Lagos, namely, Methodist, Anglican, Baptist, and Presbyterian.

Please note that this information is solely for academic purposes and can only be used as for such. Thank you very much for your kind cooperation. 


\section{Personal Profile: Could you please introduce yourself and church?}

Name

Sex

Age

Church

Location

Occupation

Position in Church

Date of Interview

1. Does your church align itself with the Wesleyan doctrine of holiness or sanctification?

2. What are the main doctrinal emphases of your denomination?

3. What is your church understanding of new birth/conversion experience?

4. What does your church teach about scriptural holiness or sanctification?

5. Is the holiness experience attainable here on earth?

6. What do you understand by Christian perfection?

7. Is it possible for Christians to attain perfection here on earth?

8. To what extent can a Christian be holy or perfect?

9. What do you understand by entire sanctification?

10. In which three ways or more do you suggest the church in Nigeria, including your church can align itself with Scriptural teaching of salvation and holiness?

Thanks very much and God bless! 


\section{REFERENCES}

[1] Achunike, Hilary C. Catholic Charismatic Movement in Igboland, 1970-1990. Onitsha, Nigeria: Africana-FEP Pubs. Ltd; 2009.p 49.

[2] Burgess, Richard.Times of Refreshing Revival and the History of Christianity in Africa. Bukuru, Plateau State, Nigeria: ACTS Bookshop; 2008.p.24, 7, 11, 12, 13.

[3] Steward, Benjamin. Historical background of churches in Nigeria. Nigeria: Interwale Press and Bookstores Ltd; n.d.

[4] Abodunde, Ayodeji. A Heritage of Faith a History of Christianity in Nigeria. badan: Piercewatershed; 2009.

[5] Olaiya, Joe. "Praying to See God's Promises" In: C. Peter Wagner and Joseph Thomson (Gen. Eds.). Out of Africa. Ventura, Cal. USA: Regal Books; 2004

[6] Ferguson, Sinclair B. David F. Wright and J.I. Packer (eds). New Dictionary of Theology. Nottingham, England: Inter-Varsity Press; 1998. Revival/revive p 588.

[7] Ukaoha, Eugene Ikechukwu. Introduction to the History of Christianity in West. Africa. Raola Graphics Studios; 2013.

[8] Moreau, A. Scott. Evangelical Dictionary of World Missions. Grand Rapids, Michigan: Baker Books; 2000 pp 636-637.

[9] Elwell, Walter A. Baker's Evangelical Dictionary of Biblical Theology; 1996. Grand Rapids, Michigan: Baker Books. Available from https://www.biblestudytools.com/di ctionaries/bakers-evangelicaldictionary/.

[10] Agha, U. Agha. Early European Missions to West Africa An Introduction to West African Church History.Uwani, Enugu, Nigeria: SAP Nigeria Inc.; 1999 p9.

[11] Verwer, George. Out of the Comfort Zone. Wheaton, Illinois, USA and Jos, Plateau, Nigeria: Oasis International; 2000; p17.

[12] New $7^{\text {th }}$ EditionOxford Advanced Learner's Dictionary. Tenet $\mathrm{p} 1525$

[13] Vine, N.E. (1997). Vine's Expository Dictionary of Old and New Testament Words. Nashville, Tennessee: Thomas-Nels on Publishers; 1997. "Apostolos"/ “Apostello" p30

[14] Yocum, Dale M. The Holy Way (revised ed.) Calvary College of Theology, Port-Harcourt Nigeria: Outreach Publications; 1981.p59.

[15] Reasoner, Vic (2012). A Wesleyan Theology of Holy Living for the 21 $1^{\text {st }}$ Century: The Pursuit of Perfection Across Twenty Centuries. Vol. 1. Evansville, IN: Fundamental Wesleyan Press; 2012 p 20.

[16] Oswalt, John N. Called to be Holy A Biblical Perspective. Nappanee, Indiana: Francis Asbury Press of Evangel Publishing House; 1999 p1.

[17] Cheesman, Graham.Mission Today an Introduction to Mission Studies. 14, Glencrgagh Court, Belfast: Qua Iboe Fellowship; 1997.p16.

[18] Ukachi, Austen. The Best Is Yet to Come: Pentecostal-Char ismatic Revivals in Nigeria 1914-1990s. USA: Xulon Press; 2013.p28.

[19] Bebbington, David W. Evangelicalism in Modern Britain: A History from the 1730s; 1993 to1980s. London: Routledge; 1993.

[20] Baur, John. 2000 Years of Christianity in Africa. Nairobi, Kenya: Pauline Publications; 2009.

[21] Thomson, Alan. New Movements Reform-Rationalism-Revo lution. Church History 3: AD 1500-1800.Maryleborne Road, London: SPCK; 1976.p 112-115.

[22] Ajayi, J.F.Ade. (1965). Christian missions in Nigeria 1841-1891 The Making of a New Elite. London: Longmans.

[23] Ayandele, E.A. (1966). The Missionary Impact on Modern Nigeria 1842-1914. London: Longmans.

[24] Maxey, Gary S. (2016). Capturing a Loss Vision: Can Nigeria's Greatest Revival Live Again? Ipaja, Lagos: WATS Publications.

[25] Ajayi, S.Ademola. 2010. Baptist work in Nigeria 1850-2005 a comprehensive history. Ibadan: Book Wright.

[26] Ukaoha, Anyamagir and Diara (2013). "The Church as the solid foundation of God: Lessons for Nigerian pastors and priests."In: International Journal of Christian Theological Research, Nsukka Vol. 3 No. 1.

[27] Murray, John. Calvin on Scripture and Divine Sovereignty. England: Evangelical Press; 1960.pp 56, 64, 65.

[28] Wesley, John. 1966. A Plain Account of Christian Perfection. Kansas City, Missouri: Beacon Hill. 